\title{
Epidemic in Medieval, The Case, Ibn Khaldun, Theory of Wet Lung Infection
}

\author{
Dr Mohammadreza Shahidipak* \\ Islamic Azad University Central Tehran Branch \\ *Corresponding author: Mohammadreza Shahidipak, Islamic Azad University Central Tehran Branch
}

\section{ARTICLE INFO}

Received: 彗 October 25, 2021

Published: 慧 November 05, 2021

Citation: Mohammadreza Shahidipak. Epidemic in Medieval, the Case, Ibn Khaldun, Theory of Wet Lung Infection. Biomed J Sci \& Tech Res 39(5)-2021. BJSTR. MS.ID.006356.

Keywords: Epidemic; Hafsids; Tunisian medicine; Crusade; Frankie disease

\begin{abstract}
An interdisciplinary study of epidemic in Middle Ages has always been a fertile ground for thinking about controlling epidemic in future. Three reasons for mortality in medieval Mediterranean societies have been cited:

a) Epidemics

b) Plot of Hungary

c) Plot of political seditions, war.

Epidemic in fourteenth and fifteenth centuries that spread to all cities of Mediterranean from Iberian peninsula to Egypt, Cairo, Fez, Tunisia, Valencia , Damascus, Alexandria, Gaza, Aleppo, The Mediterranean epidemic had 1000 to 2000 victims per day in several periods of time, including (1347 to $1350 \mathrm{AD} /$ 747-751 AH). The eighth crusade as a last classic crusade in Tunisia ended by epidemic with death of Louis IX, King of France. And medicine of Islamic societies have taken measures to discover causes of epidemics and ways to deal with, repel and eliminate epidemics and explain duties of citizens an escape or settlement.The concept of contagious disease and natural and metaphysical causes of epidemic and question of nature of spread of disease and its possibility, including legitimacy or illegitimacy of gathering to pray for an epidemic. And how to bury dead of epidemic. Medieval Islamic medicine seemed to be cause of invisible infectious diseases, but it also spoke of metaphysical factors in detail about causes of epidemic. The source of epidemic and its cause is reported by Tunisian Christian-Muslim historian and physician, Constantine from Ifriqyah. He has considered origin of epidemic, western Mediterranean in his time from land of Franks called Frankish disease, and reason for its transmission is said to be infection with smell and due to tattoos. Finally, Ibn Khaldun's theory of symbol of Islamic medicine about epidemic and in last stage of its development has been expressed Comprehensive theory of medicine and anthropology can be used in different places and times that has used sociological tools in explaining epidemic and has given epidemic nature of sociological and anthropological problems, causes of which are human and society behavior. It is a kind of sociological medical accident.
\end{abstract}

\section{Mediterranean Historical Geography of Migration and Constant Population Movement}

\section{Geographical Area of the Epidemic}

The Mediterranean Sea between east and west has recorded the highest epidemic in its history. This region is witnessing large migrations. The constant movement of population to Mediterranean caused popular pressure and formation of very large cities, after fall of Andalusia, people settled in coastal cities of North Africa and population of coastal cities increased [1]. 


\section{Medieval Tunisia Epidemic Research Center}

The cities of Tunisia, Morocco ,Granada under AL-Mohads and Hafsids dynasty (1574 -1229) were center of Mediterranean medical research and center about epidemic. Tunisia was built during Hafsids period with new urban planning, and several hospitals and centers for care of patients with Pervasive diseases were built there ,Some manuscripts about epidemic are kept there. During Hafsids period, it was center of Islamic sciences, Islamic medicine, and Zaytoneh University was center of scientific references and dissemination of Islamic medicine [2]. There was a lot of correspondence with Tunisian scientists about epidemic ,Islamic medicine reached its last stage of development during Hafsids period [3]. In its social, political, and medical history, Mediterranean is witnessing simultaneous events in context of collapse of governments and cities and immigration, massive population growth, and an epidemic of widespread and collective death. These events were observed and reported by several historians during thirteenth to sixteenth centuries AD. Between these reporters, only one has made a meaningful connection between epidemic population in sociological and anthropological perspectives, and his research has been paradigmatic in explaining cause of epidemic and understanding epidemics [4] Islamic medicine in this period was superior to the medicine of the Jewish and Christian communities [5]. According to Oriental studies in North Africa, Hafsian government is period of development and transfer of Islamic medicine to Europe [6].

\section{Distribution and Nature of Diseases in Mediterranean Societies by Lyon from Ifriqyah}

One of the most important historical accounts in history of medicine is description of common diseases in Islamic West and cities around Mediterranean by Leon Constantine of Ifriqyah. He is geographical feature of spread of disease in Mediterranean coast from tenth to thirteenth century AD. And his work have international importance in understanding epidemic of diseases in Islamic and Christian Mediterranean [7].

\section{Epidemic Prevention Measures, Example of Scientific Achievements of Islamic Civilization}

History of Hafids kingdom is closed with history of epidemics such as cholera and plague in Africa, which was accompanied by several large-scale killings (every 15 or 20 years). The massacre was one of the main motivations for Tunisian physicians to conduct health research. They wanted to guide and encourage people to take health care in disease prevention by pursuing "hygiene." They produce a large number of research and compilation of dozens of treatises on health as top medicine for combating epidemic diseases are among new medical trends of end of Middle Ages in Tunisia. There are new studies on Hygiene, very extensive research in "hygiene". in epidemics condition ,as a superior medicine and hygiene has a higher status than medicine and a higher honor than pharmacology and other branches of medicine in Tunisia, and Tunisia's medical research was welcomed by neighboring countries, and Tunisian doctors were invited to those countries. Ottoman Empire, for example He was invited Abdul Karim to the court of the Ottoman Sultan for medicine. He went to Istanbul and settled in Ottoman court and took charge of hygiene and wrote a book for Ottoman Sultan Ba Yazid II(1512 ) in hygiene [8].

\section{Physical Causes , Ibn Khalun's Theory of Epidemic, Wet Lung Infection}

Many North African physicians have cited natural causes of epidemics, all of which mention air, water [9], and food infections, especially in stagnant water and mudslides, including in Mediterranean beaches of Egypt and around Nile [10]. Ibn Khalden's innovative analysis of epidemics, human behavior, and wet lung infection. Ibn Khaldun (1406) in explanation of epidemic , considers food, air pollution, environment and animals , But Ibn Khaldun's initiative is to analyze and explain the anthropology and sociology of epidemic and behavior of man, government, and society.he is a graduate of Tunisia's Zaytouna University and prime minister of Hafsids government [11].

Air Corruption: A possible summary of Ibn Khaldun's view on nature and causes of epidemic is that Ibn Khaldun considered air factor to be more important than other factors in the epidemic. In his definition, air is food of animal soul, and when air becomes corrupt, this corruption affects human temperament, which is essence of animal soul, and because air is high, disease penetrates lungs. And because of that, fever spreads to organs of body and man dies as a result of this disease [12]

Peripheral Cycle of Infection: According to Ibn Khaldo, main cause of infection, stagnation of air and lack of flow is due to increasing urbanization and its pervasiveness during heyday of governments, while naturally one of natural necessities of urbanization is that air should be right size to flow in city due to large open and empty spaces and waste regions interspersed between civilized areas [13].

Supernatural Causes of Epidemic, Effected Lung by Disease: Several metaphysical causes have been cited for epidemic, only three of which are noteworthy, one of which is cosmic impact on terrestrial events related to astronomy. The second is referred to as Jinn bite in Arabic texts of Hafsids period And third, punishment of sins and evil result of man's own actions [14].

\section{Discussion and Results}

In search of natural causes of epidemic, A review of reports on history of medicine in Mediterranean reveals two different 
perspectives on origin of epidemic. Islamic medicine is a pioneer in separating medicine from religion and metaphysical issues and has for first time spoken of microscopic causes that are beyond human sight and cause spread of disease and epidemics. The view of Islamic civilization on impact of stars and universe on production of epidemics has been prohibited from such research for several centuries because little information about it is useful, no result is desirable and efficient for people, and a lot of information cannot be obtained. In universe, there is no practical , theoretical ,scientific result that can be proposed in academic circles, and linking epidemic to jinn and advising exorcism in Islamic civilization is forbidden because jinn are normally at peace with human societies and they has nothing to do with human affairs. And attributing an epidemic to divine torment is beyond reach of human knowledge. Therefore, according to many documents of Islamic civilization from third century $\mathrm{AH}$, he turned to experimental and clinical medicine and experience and observation about the causes of epidemic and how to deal with it. It was observed that Ibn Khaldun is a clear example of experimental attempt of Islamic civilization to scientifically understand epidemic by analyzing human behavior ,society ,state with animal water, food, environment.

\section{References}

1. Mohammadreza S (2010) Analytic history of Andalusia \& Analytic history of Maghreb.

\section{ISSN: 2574-1241}

DOI: 10.26717/BJSTR.2021.39.006356

Mohammadreza Shahidipak. Biomed J Sci \& Tech Res

(c) (P) This work is licensed under Creative Commons Attribution 4.0 License

Submission Link: https://biomedres.us/submit-manuscript.php
2. Mohammadreza S (2016) Islamic civilization and culture in Hafsids period, ICESCON04_452.

3. Mohammadreza $S$ (2012) $43^{\text {rd }}$ Congress of the International Society for the History of Medicine, Padua - Abano Terme (Italy). p. 12-16.

4. Khaldun I (1999) Interoduction. p. 747.

5. Brunschwig (1988) Rober history of Ifriqyah in Hafsids period.

6. Mohammadreza S (2020) Medicine in North Africa, Encyclopedia of Islamic and Iranian Medicine, (Farhngestan ulum), Islamic Republic of Iran.

7. Mohammadreza S (2005) Tunisian medicine in medieval in Hafsids period, scientific journal of Islamic history, no 4, 2005. iSSN 2008-6431, Bib Tex l (EndNote ‘ProCite ‘Reference Manager) RIS.

8. Ibids.

9. Gorj S (2005) Interoduction to history of sciences.

10. (1971) Ibn Abi Usaibia, History of Physicians. pp. 1-195.

11. Shahidipak DM (2020) Ibn Khaldun as a paradigm for the past and future of sociology and humanity. Sociol Int J 4(5): 153-159.

12. Ibn Khaldun, Ibids.

13. (1968) Ibn Khaldun. The Muqaddimah, translated by Rosental

14. Mohammadreza S (2005 to 2020) This research paper is based on the author's articles and books on Islamic medicine in the Middle Ages since 2005 as you say in detail bellow: All the author's works are available online on the Internet and in cyberspace and can be downloaded for free. The materials of this research are in my doctoral dissertation.

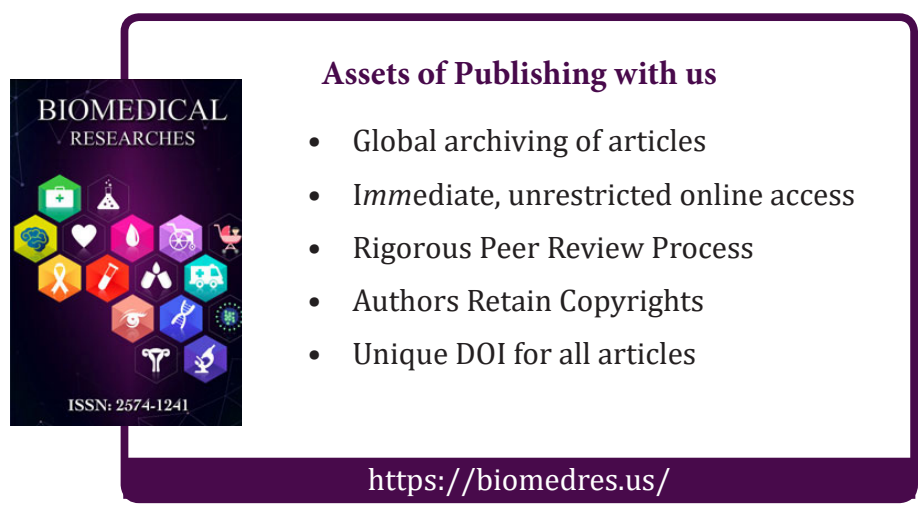

